\title{
Beneficial Effects of (pGlu-GIn)-CCK-8 on Energy Intake and Metabolism in High Fat Fed Mice are Associated with Alterations of Hypothalamic Gene Expression
}

Authors

Affiliation

\author{
I. A. Montgomery, N. Irwin, P. R. Flatt
}

SAAD Centre for Pharmacy and Diabetes, University of Ulster, Coleraine, Northern Ireland, UK received $\quad 08.10 .2012$ accepted 03.12 .2012

\section{Bibliography DOI http://dx.doi.org/ 10.1055/s-0032-1331767 Published online: January 11, 2013 Horm Metab Res 2013; 45: 471-473 \\ (c) Georg Thieme Verlag KG Stuttgart . New York ISSN 0018-5043}

Correspondence

\section{Dr. N. Irwin}

SAAD Centre for Pharmacy and Diabetes

University of Ulster

Coleraine

Northern Ireland BT52 1SA UK

Tel.: + 44/28/70 324574

Fax: $+44 / 28 / 70323939$

n.irwin@ulster.ac.uk

\begin{abstract}
$\nabla$

Cholecystokinin (CCK) is a gastrointestinal hormone with potential therapeutic promise for obesity-diabetes. The present study examined the effects of twice daily administration of the $\mathrm{N}$-terminally modified stable CCK-8 analogue, (pGlu-Gln)-CCK-8, on metabolic control and hypothalamic gene expression in high fat fed mice. Sub-chronic twice daily injection of (pGluGln)-CCK-8 for 16 days significantly decreased body weight $(p<0.05)$, energy intake $(p<0.01)$, circulating blood glucose $(p<0.001)$, and plasma insulin $(p<0.001)$ compared to high fat controls. Furthermore, (pGlu-Gln)-CCK-8 markedly
\end{abstract}

\section{Introduction}

$\nabla$

Cholecystokinin (CCK), a gut peptide secreted by endocrine I-cells in response to feeding, regulates short-term energy balance through stimulation of central satiety [1]. CCK exerts this effect through binding to specific $\mathrm{CCK}_{1}$ Rs on vagal afferent neurons, activating central pathways involved in energy regulation [1]. Vagal afferents are essential to CCK-induced satiety, as demonstrated through studies displaying an increase in vagal afferent discharge after peripheral CCK injection, or reduction in satiety following surgical destruction of peripheral vagal terminals [2]. Notably, these vagal afferents innervate neurons on the nucleus of the tractus solitaries (NTS) that terminate in the hypothalamus [1].

Accumulating evidence suggests that sustained $\mathrm{CCK}_{1} \mathrm{R}$ activation is a potential therapeutic option for obesity and related metabolic disease. Thus, we have recently developed the potent and stable $\mathrm{CCK}_{1} \mathrm{R}$ agonist, (pGlu-Gln)-CCK-8, an enzymatically stable CCK-8 analogue, with a significantly prolonged biological half-life [3]. We have shown that (pGlu-Gln)-CCK-8 causes sustained weight improved glucose tolerance $(\mathrm{p}<0.05)$ and insulin sensitivity $(p<0.05)$. Assessment of hypothalamic gene expression on day 16 revealed significantly elevated NPY $(p<0.05)$ and reduced POMC $(\mathrm{p}<0.05)$ and MC4R $(\mathrm{p}<0.05)$ mRNA expression in (pGlu-Gln)-CCK-8 treated mice. High fat feeding or (pGlu-Gln)-CCK-8 treatment had no significant effects on hypothalamic gene expression of receptors for leptin, $\mathrm{CCK}_{1}$ and GLP-1. These studies underscore the potential of (pGlu-Gln)-CCK-8 for the treatment of obesity-diabetes and suggest modulation of NPY and melanocortin related pathways may be involved in the observed beneficial effects.

\section{Materials and Methods \\ $\nabla$ \\ Peptides}

(pGlu-Gln)-CCK-8 was obtained from American peptide company (Sunnyvale, USA) and characterized as described previously [3].

\section{Animals}

Male Swiss NIH mice (Harlan UK Ltd.; 10-12 weeks) had free access to drinking water and standard rodent maintenance ( $10 \%$ fat, $30 \%$ protein and $60 \%$ carbohydrate, Trouw Nutrition, Cheshire, UK) or high fat (45\% fat, $35 \%$ carbohydrate and $20 \%$ protein, Special Diet Services, UK) 
Table 1 Effects of (pGlu-Gln)-CCK-8 on metabolic parameters in high fat fed mice.

\begin{tabular}{|c|c|c|}
\hline Parameter & High fat & (pGlu-GIn)-CCK-8 \\
\hline Accumulated food intake (kJ) & $1710.5 \pm 19.4$ & $1497.3 \pm 45.3^{*}$ \\
\hline Body weight (g) & $50.3 \pm 1.6$ & $43.3 \pm 1.3^{* *}$ \\
\hline Nonfasting glucose (mM) & $25.9 \pm 2.0$ & $15.1 \pm 1.1^{* * *}$ \\
\hline Nonfasting insulin (pM) & $1684.3 \pm 130.4$ & $494.6 \pm 109.1^{* * *}$ \\
\hline $\begin{array}{l}\text { Glucose tolerance: } 0-60 \mathrm{~min} \\
\text { glucose AUC (mM } \cdot \min )\end{array}$ & $498.5 \pm 70.4$ & $313.4 \pm 31.1^{*}$ \\
\hline $\begin{array}{l}\text { Insulin sensitivity: glucose } \\
0-60 \text { min AAC (mM } \cdot \min )\end{array}$ & $83.1 \pm 6.1$ & $108.2 \pm 7.9^{*}$ \\
\hline \multicolumn{3}{|c|}{$\begin{array}{l}\text { Parameters were measured after } 16 \text { days twice daily treatment with saline or (pGlu- } \\
\text { Gln)-CCK- } 8 \text { ( } 25 \mathrm{nmol} / \mathrm{kg} \text { body wt). For glucose tolerance, glucose }(18 \mathrm{mmol} / \mathrm{kg} \\
\text { body wt) was administered in nonfasted mice and } 0-60 \text { min plasma glucose AUC } \\
\text { values calculated. For insulin sensitivity, insulin ( } 20 \mathrm{U} / \mathrm{kg} \text { body wt) was administered } \\
\text { in nonfasted mice and } 0-60 \text { min AAC values calculated. Values are mean } \pm \text { SEM for } 6 \\
\text { mice. }{ }^{*} \mathrm{p}<0.05,{ }^{*} \mathrm{p}<0.01 \text {, and }{ }^{* * *} \mathrm{p}<0.001 \text { compared to high fat group }\end{array}$} \\
\hline
\end{tabular}

diet as appropriate. Prior to commencement of studies, high-fat mice were maintained on high fat diet from 6 weeks of age for 140 days. All animal experiments were carried out in accordance with the UK Animals (Scientific Procedures) Act 1986. The animals were housed individually in an air-conditioned room at $22 \pm 2{ }^{\circ} \mathrm{C}$ with a 12 -h light/12-h darkness cycle.

\section{In vivo studies}

Over a 16-day period, high fat mice on a reversed light cycle (lights off between 09:30-21:30h) received twice daily i.p. injections (09:00 and 17:00 h) of either saline vehicle $(0.9 \%(\mathrm{w} / \mathrm{v})$, $\mathrm{NaCl}$ ) or (pGlu-Gln)-CCK-8 ( $25 \mathrm{nmol} / \mathrm{kg}$ body wt). Body weight, total accumulated food intake, nonfasting plasma glucose and insulin concentrations were recorded on day 16. In addition, at the end of the study, i.p. glucose tolerance $(18 \mathrm{mmol} / \mathrm{kg}$ body $\mathrm{wt}$ ) and insulin sensitivity (20U/kg body $\mathrm{wt}$ ) tests were performed.

\section{Gene expression}

On day 16 , hypothalamus tissue $(n=6)$ was excised and immediately snap-frozen in liquid nitrogen and stored at $-80^{\circ} \mathrm{C}$ before RNA extraction for gene expression analysis. Briefly, total RNA was isolated and purified using QIAzol lysis reagent (Qiagen, West Sussex, UK) and RNA concentration determined from the absorbance at $260 \mathrm{~nm}$. First-strand cDNA was synthesized using $2 \mu \mathrm{g}$ of total RNA at $42^{\circ} \mathrm{C}$ for $50 \mathrm{~min}$ in the presence of $0.5 \mu \mathrm{g}$ oligo dT(12-18) primer, $10 \mathrm{mM}$ dNTP and 200U Superscript II reverse transcriptase (Invitrogen, Paisley, UK) in a final volume of $20 \mu$ l using a GeneStorm GS1 Thermal Cycler (Gene Technologies Ltd, Essex, UK). Genes were amplified using specific primers for Neuropeptide Y (NPY), proopiomelanocortin (POMC), melanocortin receptor 4 (MC4R), leptinR, $\mathrm{CCK}_{1} \mathrm{R}$, glucagon-like peptide-1 (GLP-1)R and $\beta$-actin (Atcb). The DNA-denaturing step was carried out at $95^{\circ} \mathrm{C}$ for $5 \mathrm{~min}$ in a Roche LightCycler $1.5 \mathrm{car}-$ ousel-based thermal cycler (Roche Diagnostics, West Sussex, UK). cDNA amplification then commenced for 40 cycles with $95^{\circ} \mathrm{C}$ denaturation for $30 \mathrm{~s}, 58^{\circ} \mathrm{C}$ annealing for $30 \mathrm{~s}$, and $72^{\circ} \mathrm{C}$ elongation for $30 \mathrm{~s}$ with SYBR green fluorescence being read after each cycle and recorded by Roche LightCycler Software (Version 3.5) to construct an amplification curve. Gene expression was calculated from $2^{\Delta \mathrm{Ct}}$ values normalized to mouse Atcb control primer. Age-matched lean control NIH male mice maintained on standard rodent maintenance diet were used for comparative purposes.

\section{Statistical analysis}

Results are presented as mean \pm SEM. Groups of data were compared using ANOVA and unpaired Student's $t$-test. Differences were considered significant if $\mathrm{p}<0.05$.

\section{Results}

V

\section{Effects of (pGlu-Gln)-CCK-8 on metabolic control in} high fat fed mice

Twice daily treatment with (pGlu-Gln)-CCK-8 resulted in significantly $(\mathrm{p}<0.05)$ decreased accumulated food intake by day 16 compared to high fat controls. Body weights of (pGlu-Gln)CCK-8 mice were significantly $(\mathrm{p}<0.01)$ decreased, together with reductions $(\mathrm{p}<0.001)$ of circulating glucose and insulin ( $\odot$ Table 1). AUC glucose values were significantly $(p<0.05)$ lowered following i.p. glucose, and the hypoglycemic action of insulin was significantly $(\mathrm{p}<0.05)$ augmented, in (pGlu-Gln)-CCK-8 treated mice compared to high fat controls ( $\bullet$ Table 1 ).

\section{Effects of (pGlu-Gln)-CCK-8 on hypothalamic gene expression in high fat fed mice}

NPY expression was significantly $(\mathrm{p}<0.05)$ enhanced in (pGluGln)-CCK-8-treated mice compared to high fat and lean control mice ( $\bullet$ Fig. 1a). In addition, there was a significant decrease $(\mathrm{p}<0.05)$ in mRNA expression of POMC and MC4R in (pGlu-Gln)CCK-8 mice compared to high fat controls ( $\bullet$ Fig. 1b. c). Moreover, MC4R expression was returned to levels comparable with lean control mice ( $\bullet$ Fig. 1c). There were no significant differences in hypothalamic mRNA expression of leptinR, $C_{C K} R$, or GLP-1R between any of the groups ( $\bullet$ Fig. 1d-f).

\section{Discussion \\ $\nabla$}

In harmony with previous observations $[3,4]$, twice daily administration of (pGlu-Gln)-CCK-8 to high fat fed mice resulted in a marked improvement in glucose homeostasis and insulin sensitivity. Decreased accumulated energy intake was also observed in the current study, together with substantially reduced body weight and circulating glucose and insulin. We have already shown that these beneficial effects are not reproduced by simple dietary restriction, or associated with changes in energy expenditure [3]. Therefore, in this study we examined the impact of (pGlu-Gln)-CCK-8 treatment on the expression of key hypothalamic genes involved in energy balance, in an attempt to elucidate possible underlying mechanisms.

Treatment with (pGlu-Gln)-CCK-8 for 16 days in high fat fed mice resulted in an unexpected increase in NPY gene expression compared to both lean control and saline treated high fat mice. As such, increased NPY activity is generally associated with elevated food intake. Thus, normal rats receiving hypothalamic injections of an NPY expression vector display a 2-fold increase in NPY mRNA expression and develop significantly increased energy intake leading to obesity [5]. However, in agreement with the current study, hypothalamic NPY mRNA expression is decreased in $\mathrm{CCK}_{1} \mathrm{R}$ knockout rats [6]. This suggests that modulation of hypothalamic NPY signaling may play a role in CCKmediated effects on energy intake. A functional interaction between $\mathrm{CCK}_{1} \mathrm{R}$ signaling and NPY has been proposed through experiments revealing co-localization of $\mathrm{CCK}_{1} \mathrm{R}$ and NPY immunoreactivity in the hypothalamus [6]. However, we observed no 


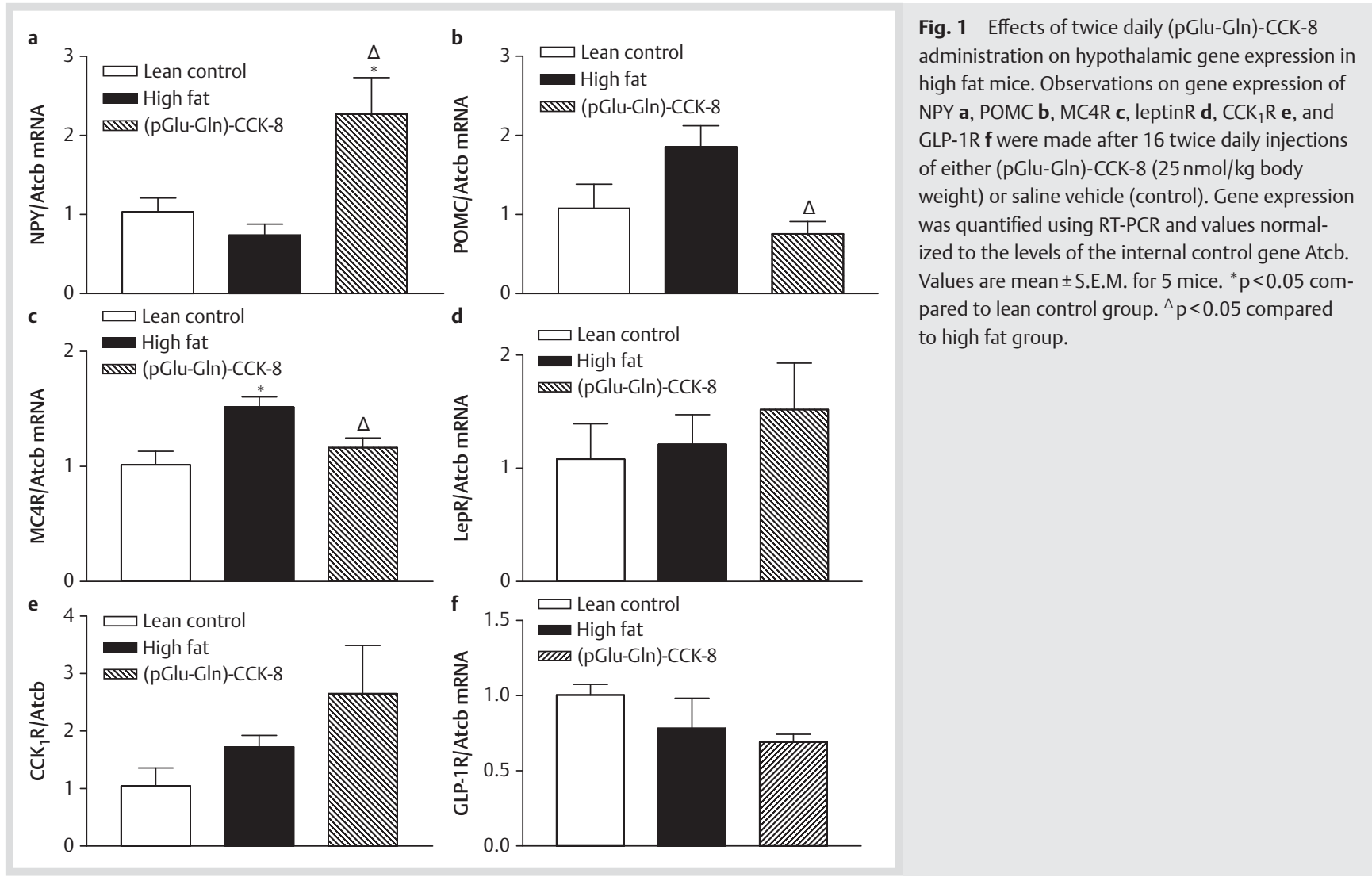

significant change in $\mathrm{CCK}_{1} \mathrm{R}$ gene expression in the current study, although there was a tendency towards increased $\mathrm{CCK}_{1} \mathrm{R}$ expression, which may have reached significance with a larger sample number.

POMC neurons in the NTS are activated by CCK and this effect is blocked by CCK antagonists [7]. This CCK/POMC effect is thought to be dependent on MC4R signaling pathways in the hypothalamus [8]. Indeed, MC4R knockout mice have delayed meal termination and reduced sensitivity to CCK [8]. Moreover, the melanocortin MC4R antagonist, SHU9119, prevents CCKinduced suppression of feeding [7]. Interestingly, POMC mRNA expression is increased in $\mathrm{CCK}_{1} \mathrm{R}$ knockout rats [6]. Thus, melanocortin signaling pathways appear to be fundamental for the satiety effect of CCK. In agreement, the present study has shown significant decreases in the hypothalamic expression of both POMC and MC4R in response to twice daily intraperitoneal injection with (pGlu-Gln)-CCK-8. We also assessed the effect of (pGlu-Gln)-CCK-8 treatment on the expression of receptors for leptin and GLP-1, since both compounds have well characterized effects on energy homeostasis and are known to interact with CCK $[9,10]$. However, there were no changes in hypothalamic gene expression of either receptor in the current study.

In conclusion, the present study indicates that the therapeutic efficacy of (pGlu-Gln)-CCK-8 is associated with modulation of NPY, POMC, and MC4R gene expression in the hypothalamus. However, further studies are required to fully delineate the mechanism of action of these effects and the potential of stable analogues of CCK-8 as novel therapeutic agents for obesitydiabetes.

\section{Acknowledgements}

These studies were supported by the SAAD Trading and Contracting Company and the Department of Education and Learning, Northern Ireland.

\section{Conflict of Interest \\ $\nabla$}

N.I. and P.R.F. hold shares with Diabetica Ltd, which has patents for exploitation of peptide therapeutics.

\section{References}

1 Rehfeld JF. Acta Physiol (Oxf) 2011; 201: 405-411

2 Ritter RC, Covasa M, Matson CA. Neuropeptides 1999; 33: 387-399

3 Irwin N, Frizelle P, Montgomery IA, Moffett RC, O'Harte FPM, Flatt PR. Diabetologia 2012; 55: 2747-2758

4 Irwin N, Montgomery IA, O'Harte FPM, Frizelle P, Flatt PR. Int J Obesity 2012; Nov 20 [Epub ahead of print]

5 Bi S, Scott KA, Hyun J, Ladenheim EE, Moran TH. Endocrinol 2005; 146: 1676-1685

6 Moran TH, Bi S. Philos Trans R Soc Lond B Biol Sci 2006; 361: 12111218

7 Millington GW. Nutr Metab (Lond) 2007; 4: 18

8 Fan W, Ellacott KL, Halatchev IG, Takahashi K, Yu P, Cone RD. Nat Neurosci 2004; 7: 335-336

9 Hisadome K, Reimann F, Gribble FM, Trapp S. Diabetes 2011; 60: 2701-2709

10 Merino B, Cano V, Guzmán R, Somoza B, Ruiz-Gayo M. Endocrinol 2008; 149: $1994-2000$ 